\title{
Antioxidant potential of Eclipta alba, a traditional medicinal herb attenuates oxidative DNA damage in vitro
}

\author{
AYYAKKANNU PURUSHOTHAMAN ${ }^{1, \boldsymbol{v}}$, A. GANESH $^{1}{ }^{1}$ PACKIRISAMY MEENATCHI $^{1}$, \\ RAMALINGAM SUNDARAM ${ }^{1}$, S. VENKATARAMANAN ${ }^{2}$ \\ ${ }^{1}$ Department of Biochemistry, Mohamed Sathak College of Arts and Science (Affiliated to the University of Madras). Chennai-600 19, Tamil Nadu, \\ India. Tel.: +91-044-24501115, Fax.: +91-044-24501114, ^email: purushothamanbiochem @ gmail.com. \\ ${ }^{2}$ Department of Diagnostic and Allied Health Sciences, Faculty of Health and Life Sciences, Management \& Science University. 40100, Shah Alam, \\ Selangor, Malaysia
}

Manuscript received: 21 April 2020. Revision accepted: 31 May 2020.

\begin{abstract}
Purushothaman A, Ganesh A, Meenatchi P, Sundaram R, Venkataramanan. 2020. Antioxidant potential of Eclipta alba, a traditional medicinal herb attenuates oxidative DNA damage in vitro. Nusantara Bioscience 12: 73-78. The plant Eclipta alba (L.) Hassk. is an important plant used in the traditional Ayurvedic, Unani systems of holistic health and herbal medicine of the East. This study aimed to evaluate the antioxidant and DNA damage protection activities of ethanolic extract of E. alba. Quantitative analysis of total phenolic content (TPC) and identification of bioactive components using Gas Chromatography-Mass Spectroscopy (GC-MS) was performed to provide scientific basis for traditional usage of this plant. To investigate the antioxidant potential, extracts were tested for their capacity to scavenge 1,1-diphenyl-2-picrylhydrazyl (DPPH·), hydrogen peroxide $\left(\mathrm{H}_{2} \mathrm{O}_{2}\right)$ and Superoxide radicals $\left(\mathrm{O}_{2}{ }^{\circ}\right)$. DNA damage protective activity of ethanol extract of $E$. alba was checked on pBluescript M13+ plasmid DNA. The Plasmid DNA was oxidized with $\mathrm{H}_{2} \mathrm{O}_{2}+\mathrm{UV}$ treatment in the absence and presence of different concentrations of $E$. alba extract $(75,150$, and $300 \mu \mathrm{g} / \mathrm{mL})$. Electrophoresis was performed using $1 \%$ agarose at $40 \mathrm{~V}$ for $3 \mathrm{~h}$ in the presence of ethidium bromide. Gel was scanned on a Gel documentation system. Bands on the gels corresponding to supercoiled circular, circular relaxed, and linearized DNA were quantified. The results of preliminary phytochemical screening of $E$. alba extract showed the presence of flavonoids, saponins, steroids, terpenoids, and tannins. The extract was found to have rich phenolics content of $26.38 \pm 2.45$ milligram of gallic acid equivalents (mg GAE/g). The extract exhibited excellent antioxidant activities. GC-MS analysis of the extract confirmed the presence of major active principles. Furthermore, the extract significantly inhibited DNA damage induced by reactive oxygen species (ROS). Altogether, the results of current study revealed that $E$. alba is a potential source of antioxidants and provides pharmacological credibility to the ethnomedicinal use of this plant in traditional system of medicine, also justifying its therapeutic application in oxidative damage induced diseases such as cancer, diabetes, and neurological disorders.
\end{abstract}

Keywords: DNA damage, Eclipta alba, free radicals, natural antioxidants, Reactive Oxygen Species, ROS

\section{INTRODUCTION}

Drugs of plant origin play a significant role in the public health care system of every nation (WHO 2019). Complementary and Alternative Medicine (CAM) systems viz. Siddha, Ayurveda, Kaempo, Unani, Folk, Sowa Rigpa, and Chinese medicines have gained their attractiveness in recent years (Golla et al. 2011). The demand for herbal medicines is bigger than ever because of their safety, efficacy, fewer side effects, and good belief of society in herbal medicines and their products (Martins Ekor 2013). Medicinal plants are significant source of natural antioxidants and herbal drugs have been used for the treatment or prevention of diseases and for the promotion of good health since ancient times (Sofowora et al. 2013). Plants are the main source of remedies for the world during 1770 s as there were only a few or no chemically synthesized drugs available (Duke 1990). For instance, Andrographis paniculata (Burm. f.) Nees (Family Acanthaceae) was the only known remedy against malarial fevers until the discovery of quinine from Cinchona trees (Sanjutha et al. 2008). Many of the drug molecules in modern pharmacology are derived from plant sources (Veeresham 2012). Some medicinal plants have noteworthy potential as source of natural antioxidants and are used to safeguard against disorders related to oxidative stress (Ting et al. 2011). However, increasing needs for natural antioxidants have provoked great importance for the discovery of potent antioxidants from plant sources (Khodaie et al. 2012). Certain plants with excellent free radical scavenging capacity proved to have a protective effect on $\mathrm{H}_{2} \mathrm{O}_{2}$-induced cytotoxicity and DNA damage (Russo et al. 2001).

Eclipta alba (L.) commonly referred to as False Daisy is a medicinal plant belonging to the family Asteraceae. The plant E. alba is a pantropical species found in Indonesia, Sri Lanka, India, Philippines, Nepal, Laos, Kampuchea, Pakistan, Thailand, Vietnam, Malaysia, Myanmar, and also in Brazil and the United States. It has been declared as an endangered plant by the United State's Department of Agriculture (Soni and Soni 2017). The ethnobotanical and ethnomedicinal survey of E. alba reported that the plant is used in the treatment of a variety of ailments in traditional and folk medicine in many 
tropical and sub-tropical countries (Jahan et al. 2014). It is also an important medicinal herb found in traditional medicine of the Eastern countries and the Indian Materia Medica that includes about 2000 drugs of natural origin. (Satheesh Naik et al. 2019). According to Saint Vallalaar, Eclipta is the number one herb in hierarchy and has been reported to possess hepatoprotective/anti-hepatotoxic, antimicrobial, anti-inflammatory, anti-diabetic activity, anti-cancer, anti-malarial, and antioxidant properties and promote hair follicle growth (Soni and Soni 2017).

Oxidative damage by reactive oxygen species (ROS) to cellular macromolecules (nucleic acids, lipids, and proteins) is implicated in the development of many diseases, including neurodegenerative disorders, cancer, liver cirrhosis, cardiovascular diseases, atherosclerosis, cataracts, diabetes, and inflammation (Aruoma 1998). Emerging research evidence has suggested that antioxidants can control the auto-oxidation by interrupting the propagation of free radicals or by inhibiting the formation of free radicals and subsequently reduce oxidative stress, improve immune function, and increase healthy longevity (Kirakosyan et al. 2003; Tan et al. 2018) It has been reported that the medicinal plants containing a wide variety of natural antioxidants, such as phenolic acids, flavonoids are of great value in preventing the onset and/or progression of many human diseases (Halliwell et al. 1992) including oxidative DNA damage.

So far, there are no reports related to the protective effect of $E$. alba against free radicals and oxidative DNA damage. The present study aimed to analyze the phytochemical components of ethanol extract of $E$. alba and to determine its protective effect against oxidative DNA damage induced by UV-photolysis of $\mathrm{H}_{2} \mathrm{O}_{2}$.

\section{MATERIALS AND METHODS}

\section{Plant samples and extraction}

Eclipta alba was collected from a local garden in Puducherry, Tamil Nadu, India. The plant was identified and authenticated by IMPCOPS (Indian Medical Practitioner's Co-operative Pharmacy and Stores Ltd.), Thiruvanmiyur, Chennai-600-041. India. The dried leaves were pulverized, using a sterile electric blender, to obtain a powdered form. The powdered form was stored in airtight glass containers, protected from sunlight until required for analysis. Powdered plant material $(50 \mathrm{~g})$ was extracted three times with $500 \mathrm{~mL}$ of $80 \%$ ethanol $(\mathrm{EtOH}) / \mathrm{H}_{2} \mathrm{O}$ while being macerated at room temperature for $24 \mathrm{~h}$ each time. The extracts were filtered under vacuum using Buchner funnel lined up with Whatman No.1 filter paper. The solvent was eliminated under vacuum using a rotary evaporator at $40{ }^{\circ} \mathrm{C}$. The extracts were used for analysis of phytochemical components, total phenolic content, GC-MS identification of bioactive compounds, antioxidant, and protective effect of $E$. alba extract against oxidative DNA damage.

\section{Phytochemical screening and total phenolic content}

Preliminary phytochemical tests were performed on the ethanol extract using standard procedures to identify the components as described Edeoga et al. (2005). The total phenolic contents were determined using Folin-Ciocalteu reagent as described by Singleton et al. (1999) with slight modifications. The extract $(200 \mu \mathrm{L})$ was mixed with 1.5 $\mathrm{mL}$ of Folin-Ciocalteu reagent (1:10 diluted with distilled water) and allowed to stand at room temperature for $5 \mathrm{~min}$. $1.5 \mathrm{~mL}$ sodium bicarbonate solution $(60 \mathrm{~g} / \mathrm{L})$ was added to the mixture and after incubation for $90 \mathrm{~min}$ at room temperature, the absorbance level was measured at $750 \mathrm{~nm}$ using a UV-Visible spectrophotometer (SICAN 2310/ Incarp, Japan). Total phenolics were quantified by calibration curve obtained from measuring the absorbance of the known concentrations of gallic acid standard solutions. The results were calculated as gallic acid equivalent (GAE) per gram extract and reported as mean value $\pm \mathrm{SD}$.

\section{DPPH radical-scavenging activity}

The DPPH radical-scavenging activity of the extract, as well as positive control butylated hydroxyanisole (BHA) was measured using the method of Koleva et al. (2002) with slight modifications, Briefly, $2.0 \mathrm{~mL}$ of methanol solution of DPPH $\left(2.0 \times 10^{-4} \mathrm{~mol} / \mathrm{l}\right)$ was mixed with equivalent aliquot of different concentrations of samples $(10,20,40,60$ and $80 \mu \mathrm{g} / \mathrm{mL})$. The tubes were incubated for $30 \mathrm{~min}$ at $37^{\circ} \mathrm{C}$. The solvent alone was considered "blank." The decrease in absorbance of test mixtures (due to quenching of DPPH free radicals) was determined at 517 nm using UV-Visible spectrophotometer; Butylated hydroxyanisole (BHA) was used as the positive control. The inhibition of the DPPH radical by the samples was calculated according to the following formula:

$$
\text { DPPH scavenging activity }(\%)=\frac{(\text { A517 of control }- \text { A517 of Sample) }}{\text { A517 of control }} \times 100
$$

\section{Assay of $\mathrm{H}_{2} \mathrm{O}_{2}$ scavenging activity}

The ability of ethanolic extract to scavenge hydrogen peroxide was determined according to the method of Ruch et al. (1989). A solution of hydrogen peroxide ( $2 \mathrm{mM})$ was prepared in phosphate buffer $(0.1 \mathrm{M}, \mathrm{pH} 7.4)$. Hydrogen peroxide concentration was determined spectrophotometrically from absorption at $230 \mathrm{~nm}$. Samples in different concentrations (10, 20, 40, 60 and 80 $\mu \mathrm{g} / \mathrm{mL})$ were added to a hydrogen peroxide solution (0.6 $\mathrm{mL}$ ). Absorbance of hydrogen peroxide at $230 \mathrm{~nm}$ was determined after 10 min against a blank solution containing phosphate buffer without hydrogen peroxide. The percentage of scavenging of hydrogen peroxide was calculated using the formula:

$$
\% \text { Scavenged } \mathrm{H}_{2} \mathrm{O}_{2}=([\mathrm{Ac}-\mathrm{As}] / \mathrm{Ac}) \times 100
$$

Where; Ac is Absorbance of the control, and As is absorbance of the sample or standard (BHA) 


\section{Assay of superoxide radical-scavenging activity}

Measurement of superoxide anion-scavenging activity of the extracts was based on the method described by Liu et al. (1997) with slight modification. The reaction mixture consisted of $1.0 \mathrm{~mL}$ of NBT $(156 \mathrm{mM}$ in $100 \mathrm{mM}$ potassium phosphate buffer $\mathrm{pH} 7.4$ ), $1.0 \mathrm{~mL}$ of $\mathrm{NADH}$ (468 $\mathrm{mM}$ in $100 \mathrm{mM}$ potassium phosphate buffer $\mathrm{pH} 7.4$ ) and $0.5 \mathrm{~mL}$ of an appropriately diluted sample (50-250 $\mu \mathrm{g} / \mathrm{mL})$. The reaction was initiated by addition of $100 \mathrm{~mL}$ of phenazine meta sulfate (PMS) $(60 \mathrm{mM}$ in $100 \mathrm{mM}$ potassium phosphate buffer $\mathrm{pH}$ 7.4) to the mixture. The tubes were incubated at ambient temperature for $5 \mathrm{~min}$ and the absorbance was measured at $560 \mathrm{~nm}$. L-ascorbic acid was used as a control. Decreased absorbance of the reaction mixture indicated increased superoxide anion scavenging activity. The percentage inhibition of superoxide anion generation was calculated using the following formula:

$\%$ Inhibition $=([\mathrm{Ac}-\mathrm{As}] / \mathrm{Ac}) \times 100$

Where; Ac is absorbance of the control, and As is absorbance of the sample or standard (BHA)

\section{Protective effect on DNA damage}

DNA damage protective activities of ethanol extract of E. alba was checked on p Bluescript M13+ plasmid DNA. Plasmid DNA was oxidized with $\mathrm{H}_{2} \mathrm{O}_{2}+\mathrm{UV}$ treatment in the presence of different concentrations of $E$. alba extract and checked on $1 \%$ agarose according to Attaguile et al. (2000) In brief, the experiments were performed in a volume of 10 in a microfuge tube containing $200 \mathrm{ng}$ of plasmid DNA in phosphate buffer $(7.14 \mathrm{mmol}$ phosphate and $14.29 \mathrm{mmol} \mathrm{NaCl}$ ), $\mathrm{pH} 7.4, \mathrm{H}_{2} \mathrm{O}_{2}$ was added at a final concentration of $2.5 \mathrm{mmol} / \mathrm{L}$ with and without $1 \mu \mathrm{L}$ of $(75$, 150 and $300, \mu \mathrm{g} / \mathrm{mL}$ ) ethanol extract of $E$. alba. The reactions were initiated by UV irradiation and continued for $5 \mathrm{~min}$ on the surface of a UV transilluminator at $300 \mathrm{~nm}$ under room temperature. After irradiation, the reaction mixture $(10 \mu \mathrm{L})$ with gel loading dye was placed on $1 \%$ agarose gel for electrophoresis. Electrophoresis was performed at $40 \mathrm{~V}$ for $3 \mathrm{~h}$ in the presence of ethidium bromide $(10 \mathrm{mg} / \mathrm{mL})$. Untreated pBluescript M13+ plasmid DNA was used as a control in each run of gel electrophoresis along with partial treatment (i.e. only UV treatment and only $\mathrm{H}_{2} \mathrm{O}_{2}$ ). Percent inhibition of the DNA strand scission was calculated as follows:

$$
\text { Inhibition }(\%)=\mathrm{I}-[(\mathrm{Sm}+\mathrm{a}-\mathrm{Sc}) /(\mathrm{Sm}-\mathrm{Sc})]
$$

Where; $\mathrm{Sm}+\mathrm{a}$ is the percentage remaining supercoiled after treatment with mix plus agent, Sc is the percentage remaining supercoiled in control untreated plasmid and Sm is the percentage remaining supercoiled with mix without agent (Fukuhara and Miyata 1998). Gel was scanned on a Gel documentation system (Gel-Doc-XR; BioRad, Hercules, CA, USA). Bands on the gels were quantified discovery series Quantity One program (BioRad, USA).

\section{Data analysis}

Data are presented as the mean \pm standard deviation (SD). Significant differences among the groups were determined by one-way analysis of variance (ANOVA) using SPSS 16.0 software package program.

\section{RESULTS AND DISCUSSION}

\section{Phytochemical screening and TPC}

The results of preliminary phytochemical screening of E. alba (Table 1) revealed the presence of tannins, saponins, flavonoids, terpenoids, cardiac glycosides, alkaloids, and steroids. The total phenolic content (TPC) of E. alba extract was found to be $26.38 \pm 2.45 \mathrm{mg}$ gallic acid equivalent (GAE) per gram plant extract (Table 2).

Phytochemical screening of plants is of paramount importance in identifying new sources of active compounds having medicinal significance and benefit from the utilization of available natural sources (Mungole Arvind et al. 2010). In the present study, phytochemical screening of the E. alba revealed that the plant is rich in tannins, saponins, flavonoids, terpenoids, cardiac glycosides, alkaloids, and steroids. The phenolic compounds are one of the largest and the most ubiquitary plant metabolites, which attracted great attention in relation to their potential for beneficial health effects. The total phenolic content of $E$. alba was found to be $26.38 \pm 2.45 \mathrm{mg}$ Gallic acid equivalent/g of extract. The high amount of total phenolic content in the extract justified its high antioxidant activities. Therefore, the antioxidant activity observed in the present study may be due to the presence of rich phenolic compounds in the plant extract.

\section{GC-MS identification of bioactive components}

The ethanol extract of $E$. alba contained rich phytochemical components which in turn resulted in the identification of fifteen different compounds by GC-MS analysis. The prevailing bioactive components (peak area greater than or equal to $2 \%$ ) with their Retention time (RT) are presented in Table 3 and Figure 1.

Table 1. Qualitative analysis of phytochemical components of Eclipta alba

\begin{tabular}{lc}
\hline Phytochemical components & Present/absent \\
\hline Tannins & + \\
Saponins & + \\
Flavonoids & + \\
Terpenoids & + \\
Cardiac glycosides & + \\
Alkaloids & + \\
Steroids & + \\
\hline
\end{tabular}

Note: + indicates presence

Table 2. Yield of ethanolic extract and total phenolic contents in ethanolic extract of Eclipta alba leaves

\begin{tabular}{cc}
\hline $\begin{array}{c}\text { Yield of ethanol } \\
\text { extract }(\%)\end{array}$ & $\begin{array}{c}\text { Total phenolic contents (TPC) } \\
\text { (mg gallic acid equivalent /g of extract) }\end{array}$ \\
\hline $14.47 \pm 2.36$ & $26.38 \pm 2.45$ \\
\hline
\end{tabular}

Note: *Values are expressed as mean \pm standard deviation 


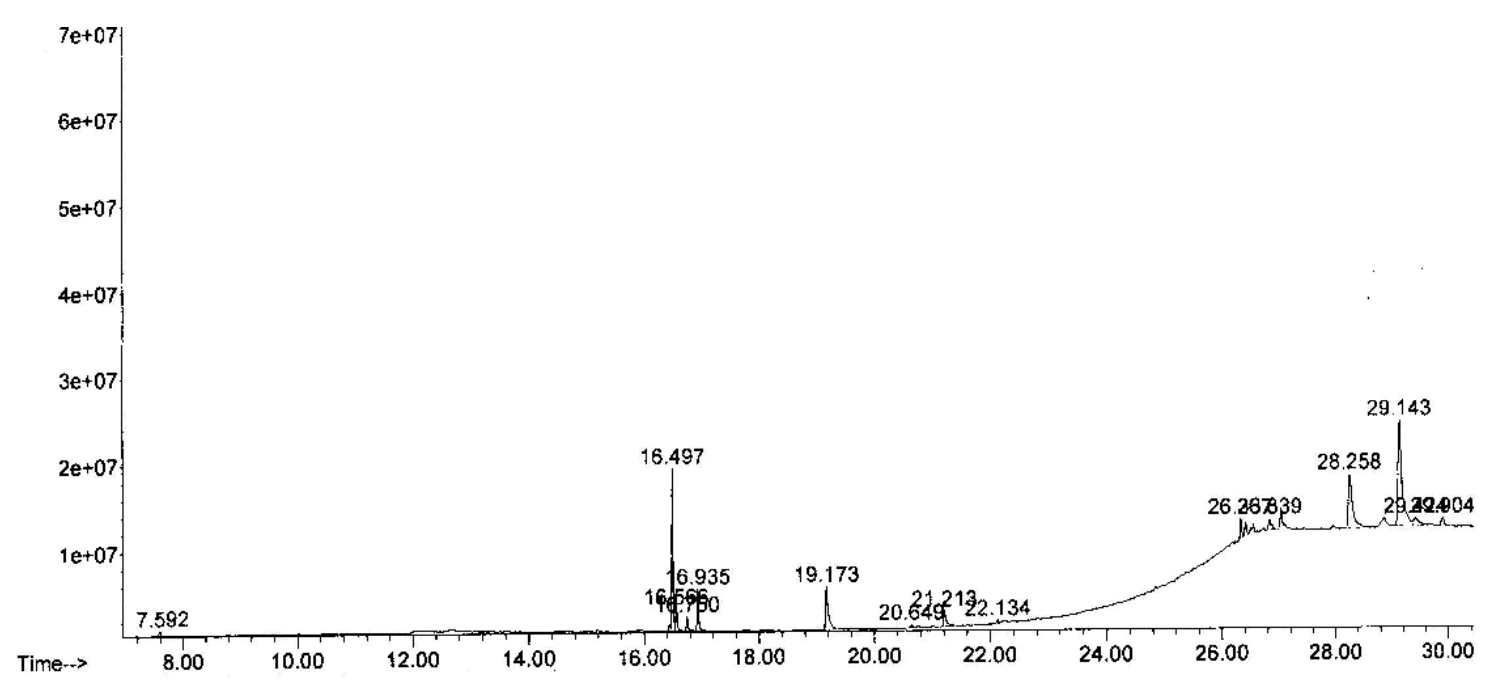

Figure 1. A representative GC-MS chromatogram of ethanol extract of Eclipta alba

Table 3. The prevailing bioactive components with their Retention time (RT), Peak area (\%), and name of the compound

\begin{tabular}{|c|c|c|}
\hline $\begin{array}{l}\text { Retention } \\
\text { time }\end{array}$ & $\begin{array}{c}\text { Peak area } \\
\%\end{array}$ & Name of the compound \\
\hline 16.492 & 15.55 & Bicyclo[3.1.1]heptanes, 2,6,6-trimethyl-, [1R-(1.alpha.,2.beta.,5.alpha.)]-Bicyclo[10.8.0]eicosane, (E)- \\
\hline 16.564 & 3.06 & $\begin{array}{l}\text { 2-Hexadecene, 3,7,11,15-tetramethyl-, }\left[\mathrm{R}-\left[\mathrm{R}^{*}, \mathrm{R}^{*} \text {-(E)]]-cyclohexane, 1,2,3-trimethyl-trans-1-Butyl-2- }\right.\right. \\
\text { methylcyclopropane }\end{array}$ \\
\hline 16.753 & 2.11 & $\begin{array}{l}\text { 3,7,11,15-Tetramethyl-2-hexadecen-1-ol } \\
\text { 1,13-Tetradecadiene }\end{array}$ \\
\hline 16.942 & 5.08 & $\begin{array}{l}\text { 3,7,11,15-Tetramethyl-2-hexadecen-1-ol } \\
\text { 2-cyclohexen-1-one, 4,4-dimethyl-cyclohexane, 1-methyl-4-(1-methylethenyl)-, trans- }\end{array}$ \\
\hline 19.178 & 8.71 & Phytol \\
\hline 21.212 & 3.58 & $\begin{array}{l}\text { Benzo[b]naptho[2,3-d]thiophene, 6,8-dimethyl-7-Methyl-5-oxo-2-p-tolyl-3,5-dihydroindolizine-6- } \\
\text { carbonitrile }\end{array}$ \\
\hline 26.832 & 2.30 & $\begin{array}{l}\text { 2H-1,3-benzoxazine, octahydro-2-(4-nitrophenyl)-, cis- } \\
\text { Methyltris (trimethylsiloxy)silane } \\
\text { Hydrocinnamic acid, benzyldimethylsilyl ester } \\
\text { 4-Methyl-2-trimethylsilyloxy-acetophenone }\end{array}$ \\
\hline 28.255 & 17.89 & $\begin{array}{l}\text { 1,4-Bis (trimethylsilyl)benzene } \\
\text { 1,4-Benzenediol, 2,5-bis (1,1-dimethylethyl)-Hydrocinnamic acid, benzyldimethylsilyl ester }\end{array}$ \\
\hline 29.141 & 32.71 & $\begin{array}{l}\text { 1-Ethynyl-3,5-dimethyladamantane2-Trifluoromethylbenzoic acid, 2-methyloct-5-yn-4-yl ester } \\
\text { Diallylphenylvinylsilane }\end{array}$ \\
\hline 29.432 & 3.36 & $\begin{array}{l}\text { 5-Methyl-2-trimethylsilyloxy-acetophenone } \\
\text { Methyltris (trimethylsiloxy)silane cyclotrisiloxane, hexamethyl- }\end{array}$ \\
\hline
\end{tabular}

\section{Antioxidant and free radical scavenging activities of Eclipta alba}

The DPPH free radical scavenging model can be used to evaluate the antioxidant activity in a relatively short time. The extract exhibited DPPH, hydrogen peroxide, and superoxide radical scavenging in a concentrationdependent manner (Table 4). The extract, which contained a considerable amount of total phenolics and flavonoids, showed a significant effect in inhibiting DPPH, reaching $68.5 \pm 4.3 \%$ at a concentration of $80 \mu \mathrm{g} / \mathrm{mL}$. The $\mathrm{IC}_{50}$ value (the amount of extract/ antioxidant material required to scavenge $50 \%$ of free radical in the assay system) for DPPH was found to be $46.19 \pm 3.5 \mu \mathrm{g} / \mathrm{mL}$. Similarly, the extract exhibited significant hydrogen peroxide and superoxide radical scavenging activities of $58.9 \pm 4.98 \%$ and $64.2 \pm 4.9 \%$, respectively at a concentration of 80 $\mu \mathrm{g} / \mathrm{mL}$. The DPPH radical, $\mathrm{H}_{2} \mathrm{O}_{2}$, and superoxide radical scavenging activities of $E$. alba indicates the strong antioxidant capacity of its components that can maintain sound health and protect the human body from oxidative damage.

\section{Protective effect of Eclipta alba on DNA damage}

Protective effect of $E$. alba on oxidative DNA damage was analyzed using on pBluescript M13+ vector (Figure 2.A-B). Figures 2.A and 2.B show the electrophoretic pattern and quantified band intensities of DNA after UVphotolysis of $\mathrm{H}_{2} \mathrm{O}_{2}$ in the absence and presence ethanol 
extract of E. alba. DNA derived from pBluescript M13+ plasmid showed two bands on agarose gel electrophoresis (lane 1); the faster-moving band corresponded to the native form of supercoiled circular DNA (96.74\% of sc DNA) and the slower moving band was the circular relaxed form (3.36\% oc DNA). EcoRI digested pBluescript M13 (+) DNA showed a major band of linearized DNA (97.85\% Lin DNA) and a very small proportion of Sc DNA $(2.15 \%)$ in lane 2. The UV irradiation of DNA in the presence of $\mathrm{H}_{2} \mathrm{O}_{2}$ (lane 3) resulted in the cleavage of sc DNA into linear form (Lin DNA). This indicated that the hydroxy radical $\left(\mathrm{OH}^{\circ}\right)$ generated from UV photolysis of $\mathrm{H}_{2} \mathrm{O}_{2}$ produced DNA strand scission, which resulted in the conversion of supercoiled circular DNA to linearized DNA. The addition of different concentrations of $E$. alba extract (in Figures 2.A and 2.B the lanes 4-6) to the reaction mixture suppressed the formation of linear DNA and induced a partial recovery of sc DNA. The percentage of Sc DNA retained on treatment with $E$. alba extract was found to be $71.4 \pm 2.62 \%, 82 \pm 3.16 \%$, and $89.63 \pm 3.35 \%$, at the concentrations of 75,150 and $300 \mu \mathrm{g} / \mathrm{mL}$, respectively.

ROS at low or moderate concentrations exert beneficial effects on cellular responses but at high levels, free radicals can damage biologically important macromolecules including DNA, proteins, and membrane lipids (Ebrahimzadeh et al. 2010). The mechanism for DNA damage, leading to mutation, is explained by the attack of
ROS on modification at DNA bases, strand break, DNA protein cross-link, and base-free site therefore oxidative damage of DNA is regarded as the etiology of number of diseases (Zhao and Liu 2009; Saenjum et al. 2010). In the present study, DNA damage inhibition potential of $E$. alba was evaluated using pBluescript M13 (+) DNA. UVphotolysis of $\mathrm{H}_{2} \mathrm{O}_{2}$ generates hydroxyl radicals, which is responsible for DNA oxidative damage observed in the current study. Earlier studies by Guha et al. (2011), have reported that the binding of hydroxyl radicals to DNA leads to strand breakage and opening, deoxyribose sugar fragmentation, and nitrogenous base modification. The attack of DNA by $\mathrm{OH}$ radical opens up the circular structure and the DNA strand becomes heavier. The oxidative DNA damage is considered as the most important mechanism in the etiology of cancer, neurological disorders, and metabolic diseases such as hypertension, diabetes, etc. Our observation corroborates with the earlier studies of Reddy et al. (2005), who reported that amla (Emblica officinalis), drumstick leaves (Moringa oleifera), and raisins (Vitis vinifera) are more effective in controlling oxidative damage as they possess rich sources of natural antioxidants. From the results of this study, it can be inferred that the plant E. alba has immense potential as a natural antioxidant and free radical scavenger and may be valuable in treating diseases of oxidative stress.

Table 4. DPPH, hydrogen peroxide, and superoxide radical scavenging activities of Eclipta alba extract in comparison with butylated hydroxyanisole (BHA, positive standard).

\begin{tabular}{ccccccc}
\hline \multirow{2}{*}{$\begin{array}{c}\text { Concentration } \\
(\boldsymbol{\mu g} / \mathbf{m L})\end{array}$} & \multicolumn{2}{c}{ \% Inhibition } & \multicolumn{2}{c}{ \% Scavenged } \\
\cline { 2 - 6 } & \multicolumn{2}{c}{ DPPH } & Hydrogen peroxide & \multicolumn{2}{c}{ Superoxide } \\
\cline { 2 - 7 } & $14.3 \pm 0.86$ & $27.4 \pm 1.2$ & $14.8 \pm 1.73$ & $38.9 \pm 2.7$ & $16.7 \pm 3.2$ & $31.8 \pm 2.6$ \\
\hline 10 & $35.6 \pm 1.8$ & $46.7 \pm 2.6$ & $28.4 \pm 2.48$ & $56.7 \pm 4.5$ & $29.6 \pm 3.9$ & $56.4 \pm 5.4$ \\
20 & $47.2 \pm 3.4$ & $58.9 \pm 3.5$ & $32.7 \pm 3.11$ & $69.6 \pm 5.2$ & $42.3 \pm 4.8$ & $61.8 \pm 4.5$ \\
40 & $56.8 \pm 4.2$ & $70.2 \pm 4.2$ & $49.6 \pm 4.76$ & $81.4 \pm 4.9$ & $53.4 \pm 5.7$ & $77.3 \pm 4.8$ \\
60 & $\mathbf{6 8 . 5} \pm \mathbf{4 . 3}$ & $\mathbf{9 1 . 6} \pm \mathbf{3 . 7}$ & $\mathbf{5 8 . 9} \pm \mathbf{4 . 9 8}$ & $\mathbf{9 8 . 2} \pm \mathbf{4 . 6}$ & $\mathbf{6 4 . 2} \pm \mathbf{4 . 9}$ & $\mathbf{8 6 . 2} \pm \mathbf{3 . 8}$ \\
\hline 0 & &
\end{tabular}

Note: BHA was used as a reference antioxidant. Values are expressed as mean \pm standard deviation of three independent experiments.

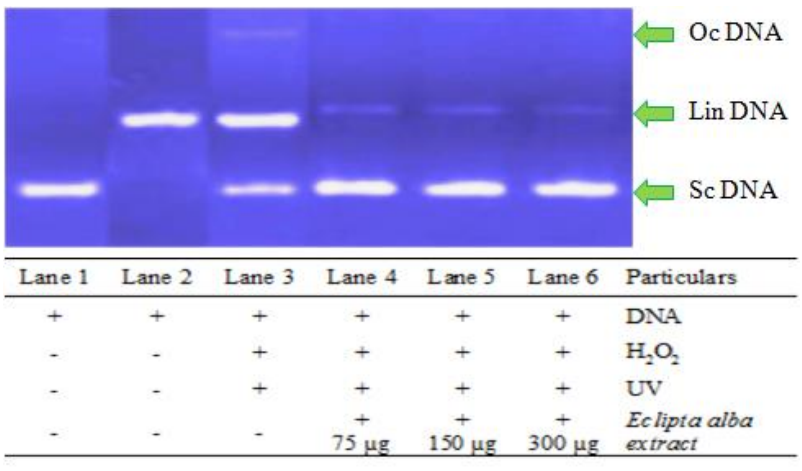

A

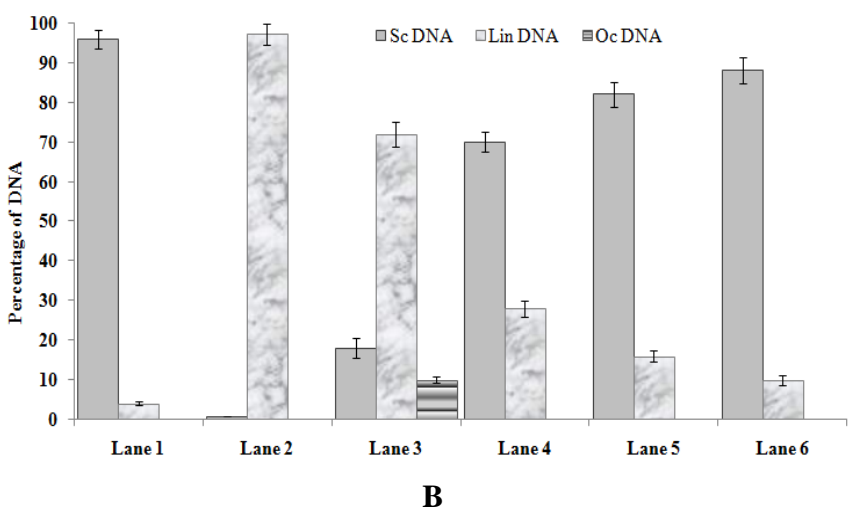

Figure 2.A. The electrophoretic pattern of DNA after UV-photolysis of $\mathrm{H}_{2} \mathrm{O}_{2}$ in the absence and presence of different concentrations of Eclipta alba Extract. B. Quantified band intensity for the Sc-DNA, Lin DNA and Oc-DNA in different lanes. Lane 1: Control DNA, Lane 2: Linearized pBluescript M13 (+) DNA (EcoRI digest), Lane 3: DNA + $\mathrm{H}_{2} \mathrm{O}_{2}(2.5 \mathrm{mM})+\mathrm{UV}$, Lane 4: DNA + $75 \mu \mathrm{g} / \mathrm{mL}$ of EaE+ $\mathrm{H}_{2} \mathrm{O}_{2}(2.5 \mathrm{mM})+\mathrm{UV}$, Lane 5: DNA $+150 \mu \mathrm{g} / \mathrm{mL}$ of EaE+ $\mathrm{H}_{2} \mathrm{O}_{2}(2.5 \mathrm{mM})+\mathrm{UV}$, Lane 6: DNA $+300 \mu \mathrm{g} / \mathrm{mL}$ of EaE+ $\mathrm{H}_{2} \mathrm{O}_{2}(2.5 \mathrm{mM})+\mathrm{UV}$ 
In conclusion, this study is the first to report the DNA damage protective effect of $E$. alba in a comprehensive manner employing a range of in vitro assays. The results of the present study confirm that the ethanolic extract of $E$. alba possesses DNA protective properties and antioxidant activity evidenced by an excellent in vitro DPPH, $\mathrm{H}_{2} \mathrm{O}_{2}$, and superoxide radical scavenging activities. This work has gathered experimental evidence on the commonly used $E$. alba as natural antioxidant for its capacity to protect organisms and cells from oxidative DNA damage associated with aging, cancer, and degenerative diseases. Thus, E. alba may serve as an ideal candidate for a costeffective, readily utilizable natural polyphenolic phytochemicals. However, further research is under progress in our laboratory to identify individual components forming the antioxidative system and their detailed mechanism to develop their application for food and pharmaceutical industries.

\section{ACKNOWLEDGEMENTS}

The authors wish to acknowledge Sophisticated Analytical Instrument Facility (SAIF) at the Indian Institute of Technology Madras for providing GC-MS analyses of the extract and identification of bioactive compounds for the research work.

\section{REFERENCES}

Aruoma OI. 1998. Free radicals, oxidative stress, and antioxidants in human health and disease. J Am Oil Chem Soc 75 (2): 199-212.

Attaguile G, Russo A, Campisi A, Savoca F, Acquaviva R, Ragusa N, Vanella A. 2000. Antioxidant activity and protective effect on DNA cleavage of extracts from Cistus incanus L. and Cistus monspeliensis L. Cell Biol Toxicol 16 (2): 83-90.

Duke JA. 1990. Promising phytomedicinals. In: Janick J, Simon JE, Editors. Advances in new crops. Timber Press, Portland, OR.

Ebrahimzadeh MA, Nabavi SM, Nabavi SF, Bahramian F, Bekhradnia AR. Antioxidant and free radical scavenging activity of $H$. officinalis L. var. angustifolius, $V$. odorata, B. hyrcana and C. speciosum. Pak J Pharm Sci 23 (1): 29-34

Edeoga HO, Okwu DE, Mbaebie BO. 2005. Phytochemical constituents of some Nigerian medicinal plants. Afr J Biotechnol 4 (7): 685-688.

Fukuhara K1, Miyata N. 1998. Resveratrol as a new type of DNAcleaving agent. Bioorg Med Chem Lett 8 (22): 3187-3192.

Golla U, Kumar AK, Solomon Suder Raj B. 2011. Assessment of antioxidant and hypnotic activity of Unani formulation Arq Gulab. Pharmacologyonline 1: 930-941.

Guha G, Rajkumar V, Mathew L, Kumar RA. 2011. The antioxidant and DNA protection potential of Indian tribal medicinal plants. Turk $\mathrm{J}$ Biol 35: 233-242.

Halliwell B, Gutteridge JMC, Cross CE. 1992. Free radicals, antioxidants, and human disease: where are we now? J Lab Clin Med119 (6): 598 620.
Jahan R, Al-Nahain A, Majumder S, Rahmatullah M. 2014. Ethnopharmacological significance of Eclipta alba (L.) Hassk. (Asteraceae). Intl Sch Res Notices 2014: 385969.

Khodaie L, Bamdad S, Delazar A, Nazemiyeh H. 2012. Antioxidant, total phenol and flavonoid contents of two pedicularis L. species from Eastern Azerbaijan, Iran. Bioimpacts 20122 (1): 43-57.

Kirakosyan A, Seymour E, Kaufman PB, Warber S, Bolling S, Chang SC. 2003. Antioxidant capacity of polyphenolic extracts from leaves of Crataegus laevigata and Crataegus monogyna (Hawthorn) subjected to drought and cold stress. J Agric Food Chem 51 (14): 3973-3976.

Koleva II, van Beek TA, Linssen JP, de Groot A, Evstatieva LN. 2002. Screening of plant extracts for antioxidant activity: a comparative study on three testing methods. Phytochem Analysis: PCA 13 (1): 817.

Liu F, Ooi VE, Chang ST. 1997. Free radical scavenging activities of mushroom polysaccharide extracts. Life Sci 60 (10): 763-771.

Martins Ekor. 2013. The growing use of herbal medicines: issues relating to adverse reactions and challenges in monitoring safety. Front Pharmacol 4: 177.

Mungole Arvind J, Awati Ravi, Chaturvedi Alka, Zanwar Prakash. 2010. Preliminary phytochemical screening of Ipomoea obscura (L)-A hepatoprotective medicinal plant. Intl J Pharm Tech Res 2 (4): 23072312

Reddy V, Urooj A, Kumar A. 2005. Evaluation of antioxidant activity of some plant extracts and their application in biscuits. Food Chem 90 (1-2): 317-321.

Ruch RJ, Cheng SJ, Klaunig JE. 1989. Prevention of cytotoxicity and inhibition of intercellular communication by antioxidant catechins isolated from Chinese green tea. Carcinogenesis 10 (6): 1003-1008.

Russo A, Izzo A, Cardile V, Borrelli F, Vanella A. 2001. Indian medicinal plants as antiradical and DNA cleavage protectors. Phytomedicine 8 (2): 125-132.

Saenjum C, Chaiyasut C, Kadchumsang S, Chansakaow S, Suttajit M. 2010. Antioxidant activity and protective effects on DNA damage of Caesalpinia sappan L. extract. J Med Plants Res 4: 1594-1600.

Sanjutha S, Subramanian S, Rani I, Maheswari J. 2008. Integrated nutrient management in Andrographis paniculata. Res J Agric Biol Sci 4 (2): 141-145.

Satheesh Naik K, Gurushanthaiah M, Kavimani M, Mahesh GM. 2019. Extraction of phytochemical constituents from the root of Eclipta alba through gas chromatography-mass spectrometry procedure. Intl $\mathbf{J}$ Res Pharm Sci 10 (2): 1238-1242.

Singleton VL, Orthofer R, Lamuela-Raventos RM. 1999. Analysis of total phenols and other oxidation substrates and antioxidants by means of Folin-Ciocalteu reagent. In: Packer L (ed.). Methods in Enzymology, Oxidant and Antioxidants (Part A). Vol 299. Academic Press, San Diego, CA.

Sofowora A, Ogunbodede E, Onayade A. 2013. The role and place of medicinal plants in the strategies for disease prevention. Afr J Trad Compl Altern Med 10: 210-229.

Soni KK, Soni S. 2017. Eclipta alba (L.) an ethnomedicinal herb plant, traditionally use in Ayurveda, J Horticult 4 (3): 1-4.

Tan BL, Norhaizan ME, Liew W, Rahman HS. 2018. Antioxidant and oxidative stress: a mutual interplay in age-related diseases. Front Pharmacol 9: 1162

Ting HC, Hsu YW, Tsai CF, Lu FJ, Chou MC, Chen WK. 2011. The in vitro and in vivo antioxidant properties of seabuckthorn (Hippophae rhamnoides L.) seed oil. Food Chem 125: 652-659.

Veeresham C. 2012. Natural products derived from plants as a source of drugs. J Adv Pharm Technol Res 3: 200-201.

WHO. 2019. Global report on traditional and complementary medicine 2019. World Health Organization, Geneva.

Zhao F, Liu ZQ. 2009. The protective effect of hydroxyl-Substituted Schiff bases on the radical-Induced oxidation of DNA. J Phys Org Chem 22: 791-798. 